FOLK PRACTICES IN NORTH MEXICO

Birth Customs, Folk Medicine, and Spiritualism in the Laguna Zone 
THIS PAGE INTENTIONALLY LEFT BLANK 
Latin American Monographs, No. 2

Institute of Latin American Studies

The University of Texas 
THIS PAGE INTENTIONALLY LEFT BLANK 


\section{FOLK PRACTICES \\ IN NORTH MEXICO}

Birth Customs, Folk Medicíne, and Spiritualism in the Laguna Zone

ISABEL KELLY

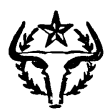

PUBLISHED FOR THE INSTITUTE OF LATIN AMERICAN STUDIES BY THE UNIVERSITY OF TEXAS PRESS : AUSTIN 
Library of Congress Catalog Card No. 64-10313

Copyright (C) 1965 by Isabel Kelly All Rights Reserved 